\title{
A conservation framework for the Critically Endangered endemic species of the Caribbean palm Coccothrinax
}

\author{
Brett Jestrow, Brígido Peguero, Francisco Jiménez, Raúl Verdecia \\ Lisbet González-Oliva, Celio E. Moya, William Cinea, M. Patrick Griffith \\ Alan W. Meerow, Mike Maunder and Javier Francisco-Ortega
}

\begin{abstract}
With 30 threatened species (14 categorized as Critically Endangered and 16 as Endangered, sensu IUCN), Coccothrinax (c. 54 species) is the flagship palm genus for conservation in the Caribbean Island Biodiversity Hotspot. Coccothrinax has its centre of taxonomic diversity in these islands, with c. 51 endemic species. We present a conservation framework for the 14 Critically Endangered species, found in Cuba, Haiti or the Dominican Republic. Only two species (C. jimenezii, C. montana) occur in more than one country (Haiti and the Dominican Republic). Immediate threats include oil drilling and nickel mining, intrusion of saline water into soil, urban and agricultural development, low population recruitment, uncontrolled fires, interspecific hybridization, and unsustainable ethnobotanical practices. Coccothrinax bermudezii, C. borhidiana, C. crinita ssp. crini$\mathrm{ta}, \mathrm{C}$. leonis and C. spissa are not conserved in protected areas. Coccothrinax bermudezii, C. jimenezii, C. leonis and C. nipensis are not part of ex situ collections. Based on results from a conservation project targeting $C$. jimenezii, we recommend international cooperation between the three range states to implement integrative conservation management plans,
\end{abstract}

BretT Jestrow Fairchild Tropical Botanic Garden, Miami, USA

Brígido Peguero and Francisco Jiménez Jardín Botánico Nacional, Santo Domingo, Dominican Republic

Raúl Verdecia Jardín Botánico Cupaynicú, Guisa, Granma, Cuba

Lisbet GonzÁlez-Oliva Herbario Nacional de Cuba, Instituto de Ecología y Sistemática, La Habana, Cuba

Celio E. Moya Sociedad Cubana de Botánica, Sección de Palmas, Boynton Beach, Florida, USA

William Cinea Jardin Botanique des Cayes, Cayes, Haiti

M. PAtrick Griffith Montgomery Botanical Center, Coral Gables, Miami, USA

Alan W. Meerow United States Department of Agriculture-Agricultural Research Service-Subtropical Horticultural Research Station, National Germplasm Repository, Miami, USA

Mike Maunder The Eden Project, Bodelva, Cornwall, UK, and National Tropical Botanical Garden, Hawaii, USA

Javier Francisco-Ortega ${ }^{*}$ (Corresponding author) Department of Biological Sciences, International Center for Tropical Botany, Kimberly Green Latin American and Caribbean Center, Cuban Research Institute, Florida International University, Miami, USA. E-mail ortegaj@fiu.edu

${ }^{*}$ Also at: Fairchild Tropical Botanic Garden, Miami, USA

Received 13 December 2016. Revision requested 30 January 2017. Accepted 27 April 2017. First published online 19 September 2017. plant exploration initiatives, taxonomic revisions, outreach, and fundraising. The ultimate aim of this review is to provide baseline information that will develop conservation synergy among relevant parties working on Coccothrinax conservation in Cuba, Haiti and the Dominican Republic. Such collaborations could also benefit through partnerships with botanists working in other countries.

Keywords Antilles, Arecaceae, IUCN, plant biodiversity, red lists, taxonomy, tropical islands

\section{Introduction}

Dalms are an iconic feature of the Caribbean landscape 1 and are associated with strong folk and ethnobotanical traditions (Liogier, 1978; Leiva Sánchez, 1999). The Caribbean Islands hold 103 endemic species of palms, with Cuba (65) and Hispaniola (20) hosting the majority (Moya \& Leiva Sánchez, 2000; Roncal et al., 2008; Freid et al., 2014). The islands have two endemic palm genera: Hemithrinax (four species) from Cuba and the monotypic Zombia from Hispaniola. The most widespread genera with endemic species can be divided into two major groups. The first group (c. 18 endemic species in 10 genera) has few species in the Caribbean Islands but many taxa from the Neotropical mainland. The second group comprises genera with their centre of diversity in these islands (c. 80 species in six genera: Coccothrinax, Copernicia, Gaussia, Pseudophoenix, Roystonea and Thrinax) and with few species occurring on the mainland (Zona et al., 2007; Roncal et al., 2008). Among them, Coccothrinax is the genus with the highest number of species in the Caribbean Islands.

Coccothrinax is regarded as being taxonomically difficult and in need of further systematic revision (Zona, 1997). Two prior taxonomic revisions focused on species from Cuba (León, 1939) and the southern Greater Antilles (Bailey, 1939). Prior to these two works, Burret (1929) provided a taxonomic account of the taxa on Cuba and Hispaniola. However, Burret's (1929) publication was based solely on material collected by the Swedish botanist and plant collector Leonard Ekman (1883-1931). In the 1980s the Hungarian botanist A. Borhidi (1932-) and the Caribbean botanist O. Muñiz (1937-2007) described new species for Cuba, 
resulting in a palm catalogue for the island (Muñiz \& Borhidi, 1982). Additional attempts were made to clarify the taxonomy of Coccothrinax (Nauman \& Sanders, 1991a, b), based on phylogenetic analyses of morphological traits mostly observed from cultivated plants.

The current taxonomic uncertainties within this genus arise, in part, from the work of Henderson et al. (1995), whose influential field guide for New World palms recognized only 14 species. Nevertheless, most palm taxonomists and botanists working on the Caribbean Islands (e.g. Moya \& Leiva Sánchez, 200o; Acevedo-Rodríguez \& Strong, 2012; Greuter \& Rankin, 2016) do not follow that narrow taxonomic view and still recognize many species that were synonymized by Henderson et al. (1995). For instance, C. jamaicensis and C. proctorii are currently regarded as distinct species endemic to Jamaica and the Cayman Islands, respectively (Proctor, 2012; Duno de Stefano \& Moya, 2014). Likewise, botanists from Cuba and Hispaniola still accept Coccothrinax species that Henderson et al. (1995) synonomized (e.g. González-Oliva et al., 2014, 2015; Peguero et al., 2015b; Verdecia, 2015).

The current available taxonomic framework for Coccothrinax is not the result of a single monographic endeavour, and therefore as a working taxonomy for our contribution we follow the classification system currently accepted by most palm biologists and plant taxonomists working in the region (Fig. 1). Therefore, we consider that the genus has 54 species, with 51 of these endemic to the Caribbean Islands (Fig. 1). These island endemics are restricted to the Bahamas and the Greater Antilles (except Puerto Rico). The taxonomic placement of $C$. alta, thought to be endemic to Puerto Rico and the Virgin Islands (Acevedo-Rodríguez \& Strong, 2005), needs further study. In this review, $C$. alta is considered a synonym of $C$. barbadensis following the recent treatment of Acevedo-Rodríguez \& Strong (2012).

Two Caribbean species (C. argentata and C. barbadensis) are found both on the islands and on the mainland, and only one species (C. readii) is restricted to the mainland (Fig. 1). The vast majority of Caribbean Island endemic species are single-island endemics, with the exception of C. fragrans (found on Hispaniola and Cuba). Reports of the presence of C. jamaicensis on the small islands of Providencia, Colombia (Galeano-Garces, 1986), and Swan, Honduras (Nelson \& Proctor, 1994), need to be validated by additional taxonomic studies. For intraspecific taxa, C. alexandri, C. clarensis, C. crinita and C. salvatoris have one subspecies each, and C. miraguama has three subspecies.

Given its high number of species, many with restricted ranges in the Caribbean Islands, Coccothrinax provides a good case to study regional species conservation issues in the Caribbean. We provide a review of conservation challenges and perspectives for the 14 Critically Endangered species of Coccothrinax that are restricted to the Caribbean
Islands, covering (1) relationships between taxonomy and conservation, (2) integrative species conservation management, (3) in situ and ex situ conservation, (4) plant exploration, (5) the role of DNA data in understanding phylogenetic relationships and patterns of genetic diversity, and (6) outreach and environmental education.

Based on our own conservation initiatives we assert that international collaboration within the region provides the best possible approach to deal with these six issues. Similar conservation challenges are faced by other threatened endemics of the Caribbean Islands (reviewed by Maunder et al., 2008, 2011, and Carey et al., 2014), and we propose that conservation initiatives centred on Coccothrinax could be applied effectively to other taxa. A main goal of this review is to provide a framework for land managers, conservationists, palm biologists and environmental educators that will offer a regional perspective for what we consider the flagship palm genus for conservation in the Caribbean Islands. This is particularly relevant as this Biodiversity Hotspot comprises several countries with a range of historical and sociological backgrounds (Maunder et al., 2008, 2011).

Data collection pertinent to ex situ conservation of these threatened species in botanic gardens, as well as literature reviews, were conducted during January 2016March 2017. Field observations were conducted during 2015-2016.

\section{Ecology, biology, and conservation biology of the Critically Endangered species of Coccothrinax}

\section{Red List assessments of Coccothrinax species}

Zona et al. (2007) assessed the conservation status of species of Coccothrinax of the Caribbean Islands using the IUCN Red List categories and criteria (IUCN, 2001, 2014). Other Red List assessments have targeted Coccothrinax and other endemic plant species of the Cayman Islands (Burton, 2008), Cuba (Rankin Rodríguez \& Areces Berazaín, 2003; Berazaín Iturralde et al., 2005; González-Oliva et al., 2014, 2015; González-Torres et al., 2016) and Hispaniola (Peguero \& Jiménez, 2011; Peguero et al., 2015b). Of the 51 species of Coccothrinax endemic to the Caribbean Islands, 16 are categorized as Endangered and 14 as Critically Endangered, with 10 of the latter restricted to Cuba (Fig. 2).

The Cuban endemic C. camagueyana was originally described by Muñiz \& Borhidi (1981), and is reported from the south of Sierra de Cubitas, Camagüey province (Méndez Santos et al., 1989). It was categorized as Critically Endangered by Zona et al. (2007); however, its taxonomic status is unclear, and more recently it was categorized as Data Deficient (González-Oliva et al., 2015). Field exploration led by CM in 2016 failed to find this species in the location from which it was originally reported (Moya et al., 2017a). 


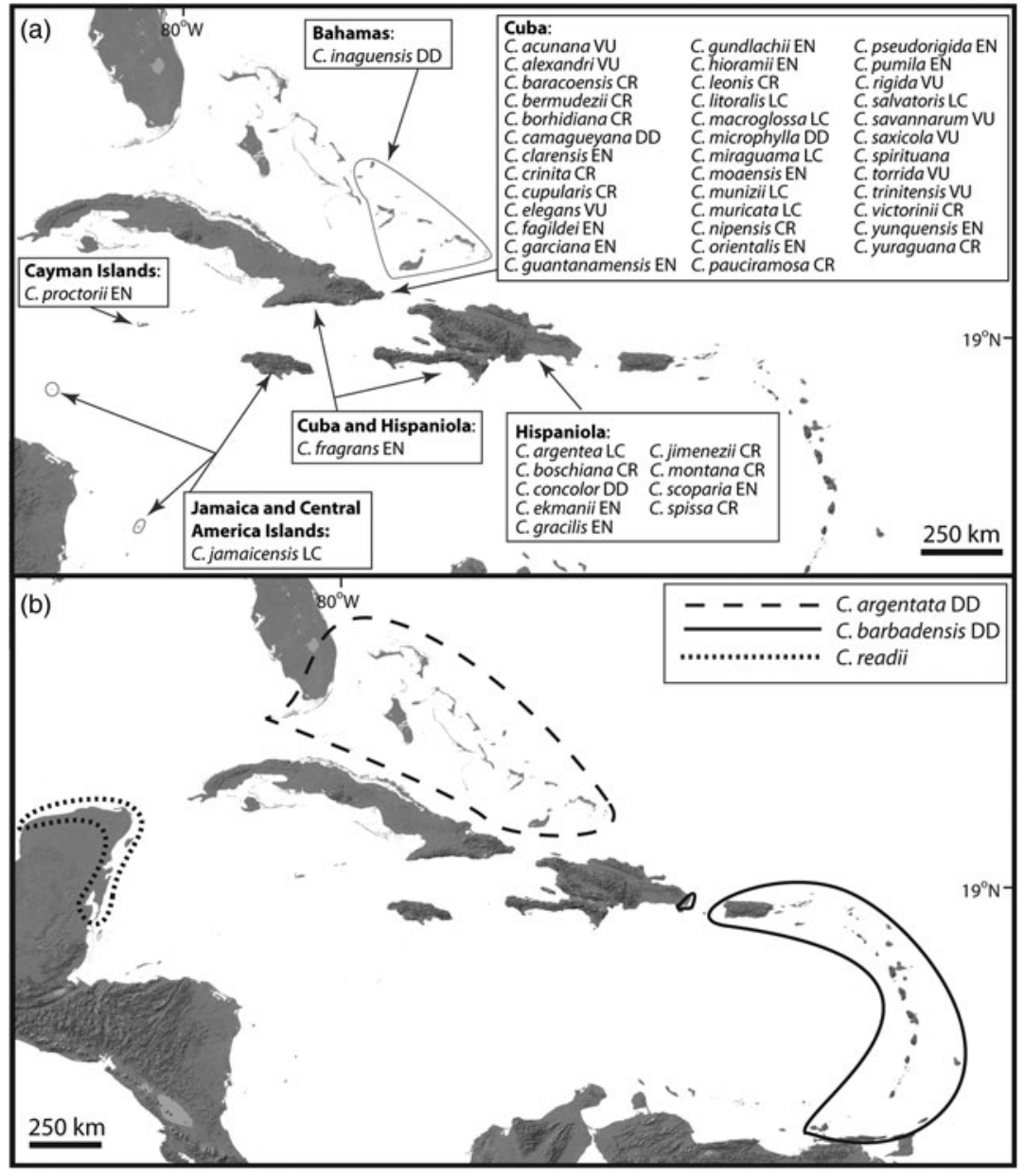

FIG. 1 Geographical distribution and Red List status of Coccothrinax species: (a) Caribbean Island endemics; (b) species found both on the Neotropical mainland and on the islands. Red List categorizations (LC, Least Concern; VU, Vulnerable; EN, Endangered; CR, Critically Endangered; DD, Data Deficient) follow the IUCN $(2001,2014)$ guidelines and come from Zona et al. (2007), Burton (2008), González-Oliva et al. (2014, 2015) and Peguero et al. (2015b). Taxonomy and geographical distribution follow Moya \& Leiva Sánchez (200o), Hoyos Fernández \& Braun (2001), Acevedo-Rodríguez \& Strong (2012), Proctor (2012), Duno de Stefano \& Moya (2014), Freid et al. (2014), Peguero et al. (2015a,b), Verdecia (2015), Greuter \& Rankin (2016), Moya et al. (2017b) and Jestrow (unpubl. data).
All of the Critically Endangered species have been assigned to this category based on the criteria B1ab or B2ab (IUCN, 2001, 2014; Table 1); i.e. they have an extent of occurrence $<100 \mathrm{~km}^{2}$ or an area of occupancy $<10 \mathrm{~km}^{2}$. They are restricted to a single locality or to a fragmented site. In addition, they show continuing decline in their extent of occurrence, area of occupancy, habitat quality, number of sites, or number of mature individuals (IUCN, 2001, 2014). Eight of these species are shown in Plates 1 and 2.

\section{Ecology, distribution and demography}

Of the 14 Critically Endangered species of Coccothrinax, most occur on limestone soils, with six Cuban taxa (five species and one subspecies) occurring on serpentine soils (Table 1). Only five species occur in coastal environments (Table 1). One of the two populations of C. jimenezii occurs on the fringes of Lago Enriquillo in the Dominican Republic, a hypersaline lake $45 \mathrm{~m}$ below sea level, which is currently expanding (Romero Luna \& Poteau, 2011), and where the wild populations are threatened by saline intrusions (Peguero et al., 2015a).
Among the inland species, the Hispaniolan endemic C. montana occurs at the highest elevations, to $1,700 \mathrm{~m}$; it was described from the Cordillera Central in the Dominican Republic and the Massif de la Selle in Haiti (Burret, 1929). However, its distribution is poorly understood, with populations reported from three disjunct sites in the Dominican Republic (Cordillera Septentrional, Cordillera Central, and Sierra de Bahoruco) and two sites in southern Haiti (Massif de la Hotte and Massif de la Selle) (Burret, 1929; Judd, 1987; B. Peguero, unpubl. data). We have no recent data on population size and distribution ranges for C. montana except from the Massif de la Hotte, where there are two populations of fewer than seven individuals each (B. Jestrow, unpubl. data), and from Bahoruco, where a single population with very few individuals is known to exist. Fieldwork is needed to determine the taxonomic and distribution status of this species both in Haiti and the Dominican Republic. Reports of the Hispaniola endemic C. spissa in northern Haiti (Bailey, 1939) need to be confirmed (Henderson et al., 1990).

We have population estimates for only five of the 14 Critically Endangered species of Coccothrinax (Table 1). Coccothrinax cupularis, C. leonis, C. nipensis and 


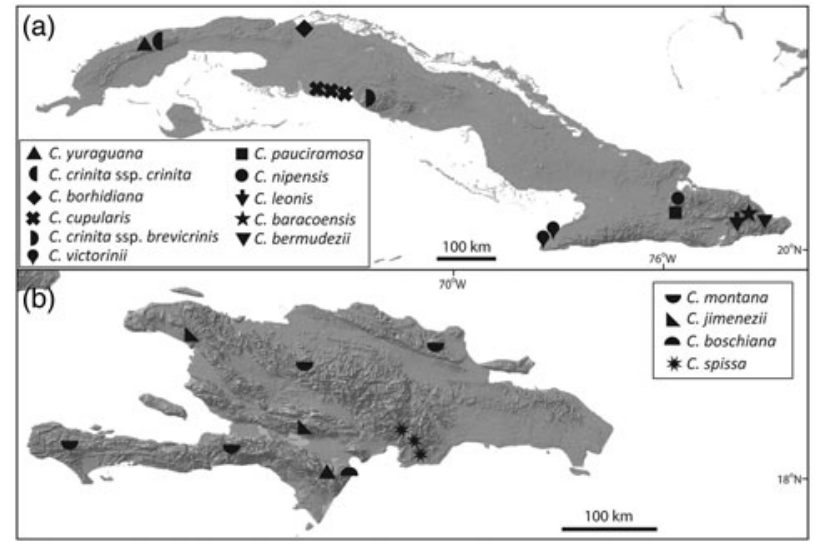

FIG. 2 Distribution of the 14 Critically Endangered species of Coccothrinax. (a) Cuban taxa; the three sites for C. cupularis represent the distribution range of the highly fragmented population of this species. (b) Hispaniolan taxa.

C. pauciramosa each have a single but dispersed population comprising scattered individuals; fieldwork is required to confirm their distribution range, population sizes and demographic status.

Population recruitment has been recorded for six taxa (Table 1). Based on preliminary field observations, both $C$. yuraguana and C. pauciramosa also appear to have recruitment in their single locations. Coccothrinax jimenezii has low levels of recruitment, with seedlings found only in the Dominican Republic population (Peguero et al., 2015a). There are no population size estimates for eight species.

\section{Conservation challenges}

Our review identified six major threats (Table 2). Two of these threats (population decline; urban, agricultural and forest development) affect 11 of the Critically Endangered species. Threats from invasive alien plant species, unsustainable ethnobotanical exploitation, and uncontrolled fires are relevant to seven taxa. Poaching for the horticulture trade has been reported only for $C$. victorinii. Four species are at risk because of nickel mining or oil drilling. One species (C. crinita) has been detected to hybridize with at least another species of the genus, and one is facing the threat of saline intrusion in soils. Based on our experience in botanic gardens, interspecific hybrids are produced easily in Coccothrinax. These threats are likely to intensify in the near future; for example, nickel mining and oil drilling are major development priorities for the Cuban economy (Wacaster et al., 2015). Furthermore, invasive alien plant species are regarded as a major challenge for plant biodiversity management in the Caribbean (Maunder et al., 2008, 2011; reviewed for Cuba by Oviedo Prieto \& González-Oliva, 2015, and González-Torres et al., 2016; reviewed for the Dominican Republic by Ministerio de
Medio Ambiente y Recursos Naturales, 2012) and will be a major concern for in situ conservation of threatened Coccothrinax species. Tourism is an important economic activity in the Greater Antilles (Gayle \& Goodrich, 1993), and is a growing industry particularly in Cuba (Hingtgen et al., 2015), where the sector is likely to undergo significant development following the easing of U.S. embargo restrictions and the establishment of formal diplomatic relationships in July 2015 (Hershberg \& LeoGrande, 2016). This may result in an intensification of human pressure on Cuban ecosystems, with a potential negative impact on endemic palms (González-Torres et al., 2016).

Five of the Critically Endangered taxa are not recorded from protected areas (Table 1), and those found within protected areas of the Dominican Republic are also of major conservation concern. From our field observations it appears that most of these protected areas (with the exception of Parque Nacional Nalga de Maco and Reserva Científica Quita Espuela) have poor conservation enforcement (Powell \& Inchaustegui, 2009; Pasachnik et al., 2016).

Eleven of the Critically Endangered taxa are cultivated in botanic gardens (Table 1). These collections are located in Cuba (five botanic gardens), the Dominican Republic (one), Spain (one), and USA (two) and they are based on wild collected germplasm. Four of the Critically Endangered species of Coccothrinax are not held in ex situ conservation collections (Table 1).

\section{Conservation biology research}

Only four taxa have been the focus of conservation research that included population size studies, ethnobotanical surveys, ecological studies or seed germination protocols (Table 2). Coccothrinax jimenezii is the only Critically Endangered species that has been the subject of conservation genetics studies (Jestrow et al., 2016a). This work was based on microsatellite markers and included the two known populations of the species, with the majority of individuals being sampled. Levels of genetic differentiation between the two populations of $C$. jimenezii are unusually high compared to those reported among populations of other palm species. This suggests that species delimitation within Coccothrinax needs to be re-evaluated, and a clear taxonomic framework for conservation initiatives is needed. Despite their small size, both populations of $C$. jimenezii have a relatively large number of unique alleles and there is no evidence of genetic bottlenecks. Only the population in Haiti exhibits evidence of inbreeding, with a moderately high positive inbreeding coefficient value (Fis $=0.232$ vs Fis $=0.093$ for the Dominican Republic population). Recent habitat fragmentation coupled with long generation times could explain the unusually high levels of genetic diversity in these Caribbean species (Jestrow et al., 2016a). 
TABLE 1 Red List assessment criteria (sensu IUCN, 2001, 2014), ecology, number of populations, demographics, and the in situ and ex situ conservation status of the 14 Critically Endangered species of Coccothrinax.

\begin{tabular}{|c|c|c|c|c|c|}
\hline Taxon & $\begin{array}{l}\text { IUCN criteria for } \\
\text { Critically Endangered } \\
\text { status }\end{array}$ & Ecology & $\begin{array}{l}\text { No. of populations/ } \\
\text { No. of individuals }\end{array}$ & In situ conservation & $\begin{array}{l}\text { Ex situ conservation } \\
\text { (No. of individuals) }\end{array}$ \\
\hline C. baracoensis & $\begin{array}{l}\text { B1ab(i,ii,iii,v)+2ab(i, } \\
\text { ii,iii,v) }{ }^{2}\end{array}$ & Scrub on serpentine, $10-200 \mathrm{~m}(\mathrm{Cuba})^{2}$ & 1/Unknown ${ }^{2}$ & $\begin{array}{l}\text { Cuchillas de Toa UNESCO Man \& the } \\
\text { Biosphere Reserve }\end{array}$ & $\mathrm{JBT}^{3}$ \\
\hline C. bermudezii & $\begin{array}{l}\text { B1ab(ii,iii,v)+2ab(ii, } \\
\text { iii,v) }\end{array}$ & $\begin{array}{l}\text { Scrub \& pine forest on serpentine, } 500-700 \mathrm{~m} \\
(\mathrm{Cuba})^{2}\end{array}$ & $1^{4} /<10,000^{2}$ & Unprotected & Unprotected \\
\hline C. borhidiana & $\begin{array}{l}\text { A4ace;B1ab(i,ii,iii,iv, } \\
\text { v) }+2 a b(i, i i, i i i, i v, v)^{6}\end{array}$ & Coastal scrub on limestone, $15-20 \mathrm{~m}(\mathrm{Cuba})^{6}$ & $1^{4,5} / 338^{6,7}$ & Unprotected & $\begin{array}{l}\text { FTBG (4), JBM (7), } \\
\text { JBN-C (3), JBT(15), MBC } \\
\text { (25), PSCT (15) }\end{array}$ \\
\hline C. boschiana & $\begin{array}{l}\text { A4acd;Blab(i,ii,iii,iv, } \\
\text { v) }\end{array}$ & $\begin{array}{l}\text { Coastal scrub on limestone, 5-200 m } \\
\text { (Dominican Republic) }^{9}\end{array}$ & $1^{5} /$ Unknown $^{9}$ & Parque Nacional Sierra Martín García & $\begin{array}{l}\text { FTBG }(5)^{3}, \text { JBN-DR }(6) \\
\text { MBC }^{3}, \text { PSCT (11) }\end{array}$ \\
\hline $\begin{array}{l}\text { C. crinita ssp. } \\
\text { crinita }\end{array}$ & $\mathrm{B} 1 \mathrm{ab}(\mathrm{iii})+2 \mathrm{ab}(\mathrm{iii})^{2}$ & $\begin{array}{l}\text { Scrub on serpentine \& human-modified sa- } \\
\text { vannah, } 20-40 \mathrm{~m}(\mathrm{Cuba})^{10}\end{array}$ & $1^{5} /$ c. $500^{2,10}$ & Unprotected & $\begin{array}{l}\text { JBC (9), JBI (11), JBN-C } \\
(70), \text { JBT (20) }\end{array}$ \\
\hline $\begin{array}{l}\text { C. crinita ssp. } \\
\text { brevicrinis }\end{array}$ & $\begin{array}{l}\text { A2acde;B1ab(i,ii,iii,v) } \\
+2 \mathrm{ab}(\mathrm{i}, \mathrm{ii}, \mathrm{iii}, \mathrm{v}) ; \mathrm{Cl}^{2}\end{array}$ & $\begin{array}{l}\text { Semi-deciduous forest } \& \text { human-modified } \\
\text { savannah on limestone, } 300 \mathrm{~m}(\mathrm{Cuba})^{11}\end{array}$ & $1^{4} / 176^{2}$ & $\begin{array}{l}\text { Área Protegida de Recursos Manejados } \\
\text { Yaguanabo }\end{array}$ & JBI (8), JBT (5) \\
\hline C. cupularis & B2ab(ii,iii,v $)^{2}$ & $\begin{array}{l}\text { Coastal, sub-coastal scrub \& evergreen forest } \\
\text { on limestone, } 5-15 \mathrm{~m}(\mathrm{Cuba})^{2}\end{array}$ & $1^{4,5} /$ Unknown $^{2}$ & $\begin{array}{l}\text { Área Protegida de Recursos Manejados } \\
\text { Península de Zapata \& Paisaje Natural } \\
\text { Protegido Guajimico }\end{array}$ & $\begin{array}{l}\text { JBN-C (11), JBI (7), JBT } \\
(4)\end{array}$ \\
\hline C. jimenezii & $\begin{array}{l}\text { A2abcd+4abcd;B1ab } \\
(\text { i,ii,iii,iv,v)+2ab(i,ii,iii, } \\
\text { iv,v);C2a(i) }{ }^{8}\end{array}$ & $\begin{array}{l}\text { Scrub on limestone fringe of hypersaline lake, } \\
\& \text { coastal scrub on limestone, } 45 \mathrm{~m} \text { (below sea } \\
\text { level, Dominican Republic), } 70-80 \mathrm{~m} \text { (Haiti) }\end{array}$ & $1^{5} / 61^{12}$ & $\begin{array}{l}\text { Dominican Republic: Parque Nacional Lago } \\
\text { Enriquillo e Isla Cabritos }\end{array}$ & Unprotected \\
\hline C. leonis & B2ab(ii,iii,v $)^{2}$ & $\begin{array}{l}\text { Scrub \& human-modified savannah on lime- } \\
\text { stone, } 100-600 \mathrm{~m}(\mathrm{Cuba})^{2}\end{array}$ & $1^{4} /$ Unknown $^{2}$ & Unprotected & Unprotected \\
\hline
\end{tabular}




\section{Table 1 (Cont.)}

\begin{tabular}{|c|c|c|c|c|c|}
\hline Taxon & $\begin{array}{l}\text { IUCN criteria for } \\
\text { Critically Endangered } \\
\text { status }\end{array}$ & Ecology & $\begin{array}{l}\text { No. of populations/ } \\
\text { No. of individuals }\end{array}$ & In situ conservation & $\begin{array}{l}\text { Ex situ conservation }{ }^{1} \\
\text { (No. of individuals) }\end{array}$ \\
\hline C. montana & $\begin{array}{l}\text { B2ab(i,ii,iii,iv,v);C1 } \\
+2 \mathrm{a}(\mathrm{i})^{8}\end{array}$ & $\begin{array}{l}\text { Montane evergreen forest, cloud forest, \& pine } \\
\text { forest on limestone, } 500-1700 \text { m (Haiti \& } \\
\text { Dominican Republic) })^{13,14}\end{array}$ & $5^{4} /$ Unknown & $\begin{array}{l}\text { Haiti: Parc National Pic Macaya, Parc } \\
\text { National Morne la Visite; Dominican } \\
\text { Republic: Reserva Científica Quita Espuela, } \\
\text { Parque Nacional Nalga de Maco }\end{array}$ & PSCT (2) \\
\hline C. nipensis & $\begin{array}{l}\text { B1ab(ii,iii,v)+2ab(ii, } \\
\text { iii,v) }\end{array}$ & $\begin{array}{l}\text { Scrub \& pine forest on serpentine, } 400-600 \mathrm{~m} \\
(\mathrm{Cuba})^{2}\end{array}$ & $1^{4} /$ Unknown $^{2}$ & Parque Nacional La Mensura-Pilotos & Unprotected \\
\hline C. pauciramosa & B2ab(ii,iii,v $)^{2}$ & $\begin{array}{l}\text { Scrub \& pine forest on serpentine, } 400-900 \mathrm{~m} \\
(\text { Cuba })^{2}\end{array}$ & $1^{4} /$ Unknown $^{2}$ & Parque Nacional La Mensura-Pilotos & $\begin{array}{l}\text { FTBG (4), JBT (5), PSCT } \\
(2)\end{array}$ \\
\hline C. spissa & $\begin{array}{l}\text { A2ace+4ace;B1ab(i,ii, } \\
\text { iii,iv,v)+2ab(i,ii,iii,iv, } \\
\text { v) }^{8}\end{array}$ & $\begin{array}{l}\text { Scrub on limestone, } 20-600 \text { m (Dominican } \\
\text { Republic) }{ }^{15,16}\end{array}$ & $3^{4,5} / 4,500$ & Unprotected & $\begin{array}{l}\text { JBN-DR (9), MBC (28), } \\
\text { PSCT (9) }\end{array}$ \\
\hline C. victorinii & $\begin{array}{l}\text { A2c;B1ab(ii,iii,v)+2ab } \\
(\text { ii,iii,v })^{2}\end{array}$ & Coastal scrub on limestone, $0-3 \mathrm{~m}(\mathrm{Cuba})^{2}$ & 2/c. $250^{2}$ & Parque Nacional Desembarco del Granma & JBC (4) \\
\hline C. yuraguana & $\mathrm{B} 1 \mathrm{ab}(\mathrm{ii})+2 \mathrm{ab}(\mathrm{ii})^{6}$ & $\begin{array}{l}\text { Scrub \& pine forest on serpentine, } 30-300 \mathrm{~m} \\
(\mathrm{Cuba})^{17}\end{array}$ & $1^{4} /$ unknown $^{6,17}$ & $\begin{array}{l}\text { Área Protegida de Recursos Manejados Mil } \\
\text { Cumbres }\end{array}$ & $\mathrm{JBN}-\mathrm{C}(7), \mathrm{JBT}^{3}$ \\
\hline
\end{tabular}

${ }^{1}$ Botanic gardens with ex situ collections based on wild collected individuals are as follows: FTBG, Fairchild Tropical Botanic Garden, USA; JBC, Jardín Botánico de Cupainicú, Cuba; JBI, Jardín Botánico de Cienfuegos; JBN-C, Jardín Botánico Nacional, Cuba; JBN-DR, Jardín Botánico Nacional, Dominican Republic; JBM, Jardín Botánico de Matanzas, Cuba; JBT, Jardín Botánico de las Tunas, Cuba; MBC, Montgomery Botanical Center, USA; PSCT, Palmetum de Santa Cruz de Tenerife, Spain

${ }^{2}$ González-Oliva et al. (2015)

${ }^{3}$ Ex situ collection has seedlings that have not yet been transplanted to the field

${ }^{4} \mathrm{Highly}$ fragmented population(s)

${ }^{5}$ Population(s) exhibit(s) recruitment

${ }^{6}$ González-Oliva et al. (2014)

${ }^{7}$ Enríquez Rodríguez et al. (2006)

${ }^{8}$ Peguero et al. (2015b)

${ }^{9}$ Mejía \& García (1997)

${ }^{10}$ Leiva Sánchez et al. (2008)

${ }^{11}$ Suárez Oropesa (2015)

${ }^{12}$ Peguero et al. (2015b)

${ }^{13}$ Burret (1929)

${ }^{14}$ Judd (1987)

${ }^{15}$ Peguero et al. (2011)

${ }^{16}$ Veloz et al. (2011)

${ }^{17}$ Urquiola Cruz et al. (2010) 


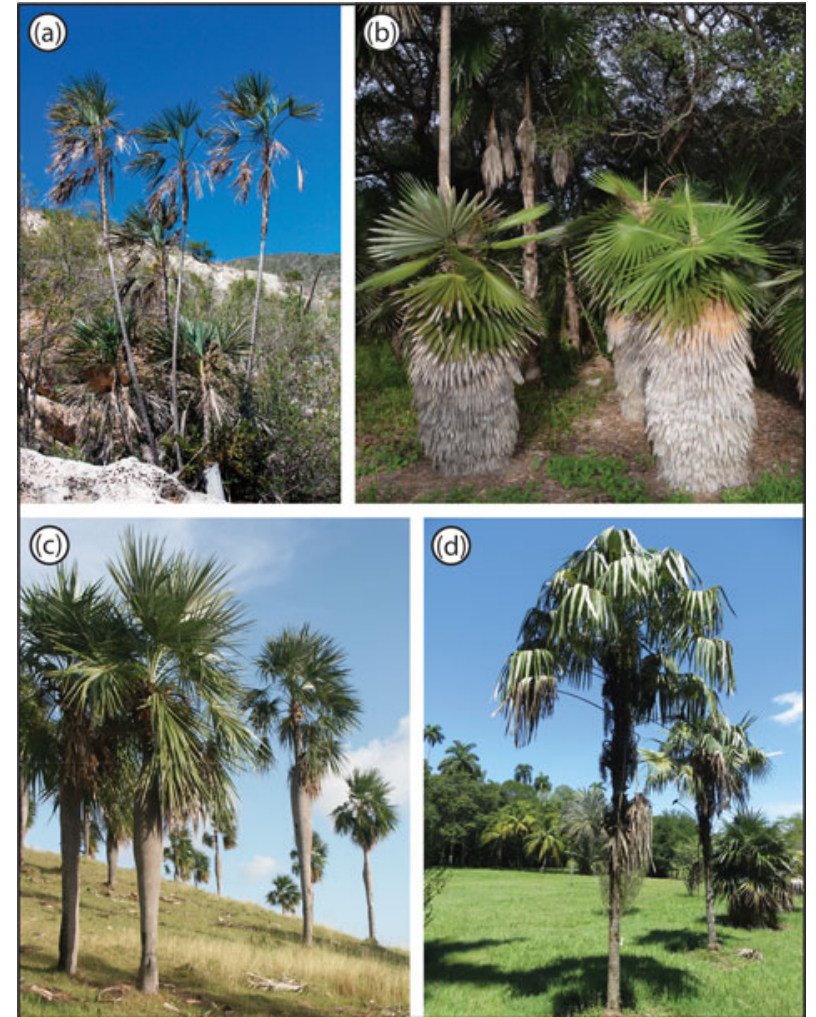

Plate 1 Critically Endangered species of Coccothrinax: (a) C. jimenezii, (b) C. borhidiana (in ex situ collection of Montgomery Botanical Center), (c) C. spissa, (d) C. victorinii (in ex situ collection of Jardín Botánico de Cupainicú). Photograph credits: (a) Francisco Jiménez, (b) Patrick Griffith, (c) Scott Zona, and (d) Raúl Verdecia.

Future genetic studies may find that at least some of the remaining Critically Endangered species of Coccothrinax for which there are currently no population genetic data available still harbour high genetic diversity.

\section{Conservation and research agenda}

The conservation management of threatened plants faces particular challenges in the Caribbean Islands (Brown et al., 2007; Maunder et al., 2008, 2011; Carey et al., 2014), most notably the diversity of political, cultural and socioeconomic systems. We propose the following conservation and research framework for Coccothrinax.

\section{Establish a regional conservation approach}

Regional cooperation is required to utilize and coordinate the existing skills and resources of the various Caribbean nations more effectively. With endemic Critically Endangered species in three countries, a comprehensive regional approach to the conservation of Coccothrinax will require collaboration between managers and plant biologists from
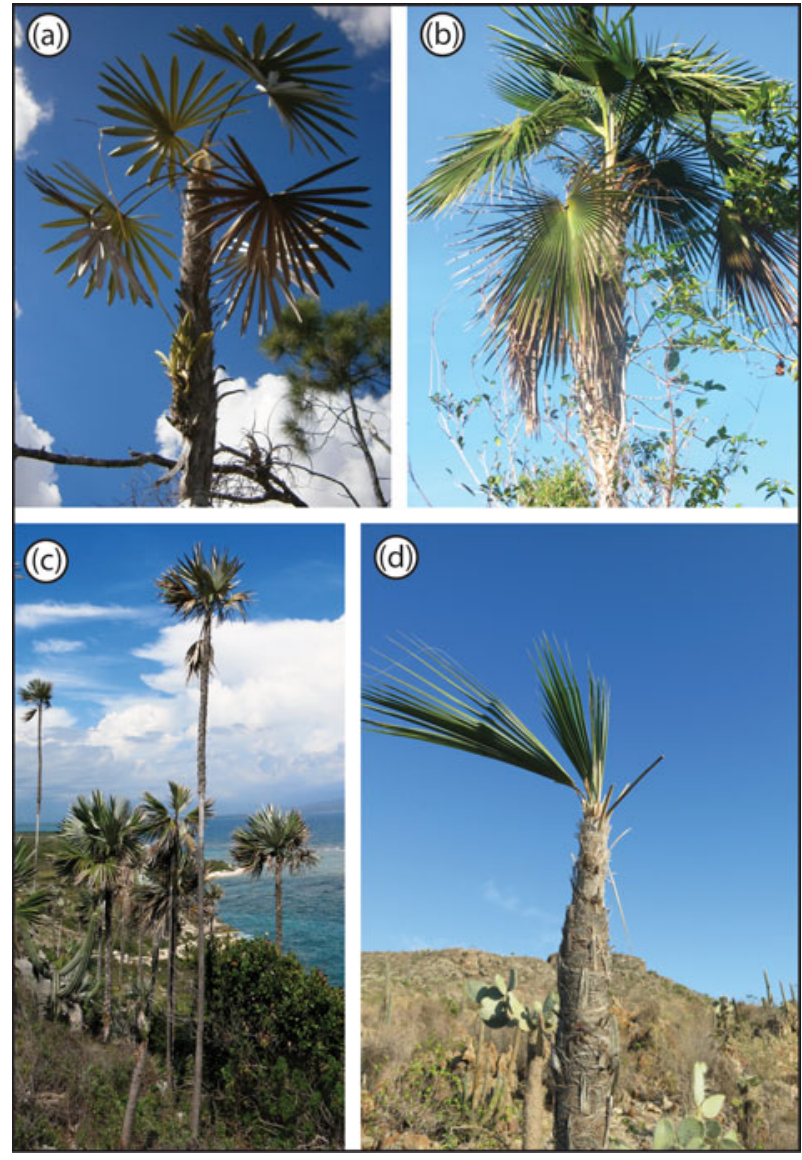

Plate 2 Critically Endangered species of Coccothrinax (all in habitat): (a) C. yuraguana, (b) C. montana, (c) C. boschiana, (d) C. jimenezii (heavily harvested to make brooms). Photograph credits: (a) Lisbet González-Oliva, (b-d) Brett Jestrow.

Cuba, the Dominican Republic and Haiti. Conservation efforts for C. jimenezii have been structured within the context of broad international cooperation led by the Jardín Botánico Nacional (Dominican Republic) and Jardin Botanique des Cayes (Haiti) in association with botanists from South Florida (Fairchild Tropical Botanic Garden, Montgomery Botanical Center, U.S. Department of Agriculture, and Florida International University). There have been extensive plant exploration expeditions in both Haiti and the Dominican Republic, including demographic studies and conservation assessments (Peguero et al., 2015a). Outreach outputs included the production of printed educational material presented during the VI Simposio Flora de La Española in June 2015 at Santo Domingo, Dominican Republic. Furthermore, we have established joint initiatives for professional progression of young Caribbean botanists, including two workshops on plant systematics in Haiti, training of one graduate student from the Dominican Republic at Florida International University (Rodríguez, 2014), and developing grant-supported projects for palm conservation through the Prince Bernhard Nature Fund, 
TABLE 2 Main conservation challenges and conservation biology research conducted for the 14 Critically Endangered species of Coccothrinax (Table 1).

\begin{tabular}{|c|c|c|c|c|c|c|c|c|}
\hline Taxon & $\begin{array}{l}\text { Nickel min- } \\
\text { ing or oil } \\
\text { drilling }\end{array}$ & $\begin{array}{l}\text { Invasive } \\
\text { alien plants }\end{array}$ & $\begin{array}{l}\text { Population } \\
\text { decline }\end{array}$ & $\begin{array}{l}\text { Urban, agricultural } \\
\text { \& forest } \\
\text { developments }\end{array}$ & $\begin{array}{l}\text { Uncontrolled } \\
\text { fires }\end{array}$ & $\begin{array}{l}\text { Unsustainable } \\
\text { ethnobotany }\end{array}$ & Other challenges & $\begin{array}{l}\text { Conservation biology } \\
\text { research }\end{array}$ \\
\hline C. baracoensis & Nickel $^{1}$ & Yes $^{1}$ & Yes $^{1}$ & Yes $^{1}$ & Yes $^{1}$ & $\mathrm{No}^{1}$ & & \\
\hline C. bermudezii & $\mathrm{No}^{1}$ & $\mathrm{No}^{1}$ & Yes $^{1}$ & Yes $^{1}$ & $\mathrm{No}^{1}$ & $\mathrm{No}^{1}$ & & \\
\hline C. borhidiana & $\mathrm{Oil}^{2,3}$ & $\mathrm{No}^{2}$ & $\mathrm{Yes}^{2}$ & $\mathrm{Yes}^{2}$ & $\mathrm{Yes}^{2}$ & $\mathrm{Yes}^{2}$ & & Ecology ${ }^{3}$ \\
\hline C. boschiana ${ }^{4,5}$ & $\mathrm{No}^{4,5}$ & $\mathrm{No}^{4,5}$ & $\mathrm{No}^{4,5}$ & $\mathrm{No}^{4,5}$ & $\mathrm{No}^{4,5}$ & $\mathrm{No}^{4,5}$ & & \\
\hline $\begin{array}{l}\text { C. crinita ssp. } \\
\text { crinita }\end{array}$ & $\mathrm{No}^{1}$ & Yes $^{1}$ & $\mathrm{No}^{1}$ & Yes $^{1,6}$ & $\mathrm{No}^{1,6}$ & Yes $^{6}$ & & Ethnobotany ${ }^{6}$, ecology 7,8 \\
\hline $\begin{array}{l}\text { C. crinita ssp. } \\
\text { brevicrinis }\end{array}$ & $\mathrm{No}^{1}$ & Yes $^{1}$ & Yes $^{1,9}$ & Yes $^{1}$ & Yes $^{1}$ & Yes $^{1}$ & Hybridization $^{10}$ & Ecology 9 \\
\hline C. cupularis & $\mathrm{No}^{1}$ & Yes $^{1}$ & Yes $^{1}$ & Yes $^{1}$ & Yes $^{1}$ & Yes $^{1}$ & & \\
\hline C. jimenezii & $\mathrm{No}^{4}$ & $\mathrm{No}^{4,11}$ & Yes $^{4,11}$ & No & $\mathrm{No}^{4,11}$ & Yes (Plate 2) ${ }^{11}$ & Saline intrusion in soils ${ }^{11}$ & $\begin{array}{l}\text { Conservation genetics }{ }^{12} \text {, } \\
\text { ecology }^{11}\end{array}$ \\
\hline C. leonis & $\mathrm{No}^{1}$ & Yes $^{1}$ & Yes $^{1}$ & Yes $^{1}$ & Yes $^{1}$ & $\mathrm{No}^{1}$ & & \\
\hline C. montana & $\mathrm{No}^{4}$ & $\mathrm{No}^{4}$ & Unknown & $\mathrm{Yes}^{4}$ & Unknown & Unknown & & \\
\hline C. nipensis & Nickel $^{1}$ & $\mathrm{No}^{1}$ & Yes $^{1}$ & Yes $^{1}$ & Yes $^{1}$ & $\mathrm{No}^{1}$ & & \\
\hline C. pauciramosa & Nickel $^{1}$ & Yes $^{1}$ & Yes $^{1}$ & Yes $^{1}$ & Yes $^{1}$ & $\mathrm{No}^{1}$ & & \\
\hline C. spissa $a^{13,14}$ & $\mathrm{No}^{4}$ & Unknown & Yes $^{13,14}$ & Yes $^{13,14}$ & $\mathrm{No}^{13,14}$ & Yes $^{13,14}$ & & $\begin{array}{l}\text { Ecology }{ }^{13,14} \text {, ethno- } \\
\text { botany }^{13,14} \text {, seed } \\
\text { germination }^{13,14}\end{array}$ \\
\hline C. victorinii & $\mathrm{No}^{1}$ & Yes $^{1}$ & Yes $^{1}$ & Yes $^{1}$ & $\mathrm{No}^{1}$ & Yes $^{1}$ & $\begin{array}{l}\text { Adult plants are transplanted } \\
\text { to gardens in urban \& resort } \\
\text { developments }\end{array}$ & \\
\hline C. yuraguana & $\mathrm{No}^{2,15}$ & $\mathrm{No}^{2,15}$ & $\mathrm{Yes}^{2,15}$ & $\mathrm{Yes}^{2,15}$ & $\mathrm{No}^{2,15}$ & $\mathrm{Yes}^{2,15}$ & & \\
\hline
\end{tabular}

${ }^{1}$ González-Oliva et al. (2015)

${ }^{2}$ González-Oliva et al. (2014)

${ }^{3}$ Enríquez Rodríguez et al. (2006)

${ }^{4}$ Peguero et al. (2015b)

"Mejía \& García (1997)

${ }^{6}$ Martínez Betancourt \& Miranda (2009-2010)

${ }^{7}$ Leiva Sánchez et al. (2008)

${ }^{8}$ Martínez Betancourt (2016)

${ }^{9}$ Suárez Oropesa et al. (2013)

${ }^{10}$ Suárez Oropesa (2015)

${ }^{11}$ Peguero et al. (2015a)

${ }^{12}$ Jestrow et al. (2016b)

${ }^{13}$ Peguero et al. (2011)

${ }^{14}$ Veloz et al. (2011)

${ }^{15}$ Urquiola Cruz et al. (2010) 
the International Palm Society, and the Mohamed bin Zayed Species Conservation Fund.

Botanists from the Dominican Republic have developed successful protocols for seed germination of C. spissa (Peguero et al., 2011; Veloz et al., 2011), which may also be applicable for the Critically Endangered species from Cuba. Across the distribution range of Coccothrinax there are field botanists and palm taxonomists who are familiar with its ecology and morphology. Their preliminary surveys suggest that hybridization detected in botanic gardens is also common in areas where species overlap (Suárez Oropesa, 2015). Caribbean island conservation biologists working with this genus have also gained experience regarding unsustainable ethnobotanical practices, and are familiar with the challenges faced by land managers and administrators regarding implementation of effective protection in the protected areas of Cuba, the Dominican Republic and Haiti. Preliminary molecular results suggest that the microsatellite loci used for C. jimenezii (Jestrow et al., 2016a) are also applicable to other species of this genus. The experiences already gained by individual teams provide a framework for development of a biodiversity strategy for Coccothrinax in the region.

\section{Establish a scientific framework for conservation}

A phylogenetic analysis and taxonomic review would clarify the conservation status of Coccothrinax taxa. For instance, C. jimenezii was described as a new species in 2013 (Mejía \& García, 2013) but molecular studies revealed uncertainties in the taxonomy of the two populations of this species (Jestrow et al., 2016a), highlighting the need for a comprehensive taxonomic revision for Coccothrinax. The morphological phylogenetic study of the genus undertaken by Nauman \& Sanders (1991a,b) identified three major groups, each one including Critically Endangered species, with high levels of homoplasy for the morphological characters. Molecular phylogenetic reconstructions for Coccothrinax (Roncal et al., 2008) did not resolve major clades. However, the conservation genetics study of $C$. jimenezii (Jestrow et al., 2016a) demonstrated the utility of microsatellite DNA markers for insights into both genetic diversity and taxonomy. There are still many gaps in knowledge of the biology of the species, and there have been no studies focused on breeding systems, plant-animal interactions, competition from invasive alien plant species, or population viability analyses.

\section{Assess and monitor wild populations}

There is a need to expand botanical field work in the range nations, particularly in Hispaniola, where there are still under-collected areas, mostly in Haiti. Although Cuba and the Dominican Republic have maintained a tradition of botanical fieldwork and research, Haiti has not had sustained support for field botany. Both the Dominican Republic and Haiti have a single botanic garden, and are key to developing a framework for future conservation initiatives. Through our inter-institutional collaborations (mostly supported by the Mohamed bin Zayed Species Conservation Fund), members of our team have been exploring areas of Haiti seldom visited since Ekman was there in the 1920s (Jestrow et al., 2016b). Fieldwork led by RV resulted in the rediscovery of C. rigida on limestone cliffs near Sagua de Tánamo (Holguín province) in 2014 (Verdecia et al., 2014). This species had not been seen since it was described by Grisebach (1866) based on material collected by the American plant explorer Charles Wright (1811-1885). Recent plant exploration activities led to the discovery of a new species, Coccothrinax spirituana, in Cuba by CM and RV (Moya et al., 2017b). This new species is currently known in a single locality in the province of Sancti Spiritus in an area of serpentine soils. Studies focusing on its demography and distribution range are in progress.

There are four Coccothrinax species that have not been located since they were originally discovered. The first, C. acunana, was described by León (1939), and plants of this species were reported to occur only in the highest mountains of Cuba, near Pico Turquino, in the province of Santiago de Cuba. The species is categorized as Vulnerable on the Red List for the Cuban flora (GonzálezTorres et al., 2016); however, its conservation status needs to be reassessed. The second species, C. microphylla, is another Cuban endemic, described by Muñiz \& Borhidi (1981). It appears to be restricted to limestone cliffs of Abra de Mariana in the lowlands of Guantanamo province. The third species, C. concolor, is known from only one herbarium collection, by Ekman in 1926. The species was described by Burret (1929) and reported from low-elevation areas with volcanic soils near Jacmel, southern Haiti (Bailey, 1939). The fourth species, C. camagueyana, not only has an uncertain taxonomic status but has not been found since it was described (Moya et al., 2017b).

\section{Ensure wild populations are protected in situ, with supporting ex situ collections}

The Critically Endangered species of Coccothrinax are facing a variety of threats. Five of the species are not present in protected areas, and four are not included in ex situ germplasm collections. An integrative approach to conservation is the most immediate priority (Esposito, 2002; Petriello \& Wallen, 2015). We are aware that in many cases official protected areas are not sufficiently resourced to ensure viability of wild populations; however, both Cuba and the Dominican Republic have protected areas with effective 
conservation management. Ex situ conservation is necessary in some cases; for instance, the Dominican Republic population of $C$. jimenezii is facing an immediate threat from the increasing water level of the hypersaline lake Lago Enriquillo, and the small population in Haiti is overharvested.

Establishing an ex situ resource should be part of an integral approach for conservation planning that involves all stakeholders (Pritchard et al., 2012; McGowan et al., 2017). Ideally this resource would be held primarily in the range state, and should ensure adequate genetic representation (Oldfield, 2009). There are botanic gardens located outside the Caribbean Islands that have ex situ conservation of palms as a mission priority (Maunder et al., 2001). Several of these (e.g. Fairchild Tropical Botanic Garden, Montgomery Botanical Center, and Palmetum of Tenerife) are already collaborating with botanists from Hispaniola and Cuba to develop representative living collections that hold duplicates of living germplasm collections and can mitigate issues regarding limited space and resources for ex situ conservation.

\section{Conclusions}

This review is derived from a 15-year collaboration focused on the palm diversity of the Greater Antilles. Based on the results of our research of the conservation biology of palms, we have proposed specific initiatives for the conservation of the most threatened species of Coccothrinax. Our collaborative approach to integrative plant conservation provides a model for other groups of conservation concern. This model is based on regional collaboration, building a framework for genetic conservation, and ensuring the professional progression of new Caribbean botanists. We acknowledge the need for increased conservation awareness of these species, particularly in the communities where they occur.

\section{Acknowledgements}

We dedicate this study to the memory of Angela T. Leiva Sánchez (1948-2014) in recognition of her legacy of supporting palm conservation research in the Caribbean Islands. This study was supported with a grant from the Mohamed bin Zayed Conservation Fund (grant number 14258589, through the International Center for Tropical Botany, Florida International University). Fairchild Tropical Botanic Garden provided matching funds to conduct molecular research. The Consejo Nacional de Investigaciones Agropecuarias y Forestales of the Dominican Republic supported in-country conservation assessments of Critically Endangered palms (project number CAD/014-05/RN, through the Consorcio Ambiental Dominicano and the Jardín Botánico Nacional). We thank Carlo Morici for providing data pertinent to the ex situ collections of Palmetum de Santa Cruz de Tenerife, and Scott Zona for sharing insights concerning taxonomic challenges associated with Coccothrinax and allied genera. This is contribution number 338 from the Tropical Biology Program of Florida International University.

\section{Author contributions}

BJ, BP, FJ and WC led field work in Hispaniola and reviewed conservation challenges for Haiti and the Dominican Republic. CEM, RV and LGO led field work in Cuba and reviewed conservation challenges for Cuba. MPG made significant contributions pertinent to ex situ conservation. AWM provided insights regarding conservation genetics. BJ, JFO and MM developed the proposed conservation and research agenda and wrote the first draft of the article. BJ and JFO led grant proposals to undertake this project, and designed and developed the structure of this study.

\section{References}

Acevedo-Rodríguez, P. \& Strong, M.T. (eds) (2005)

Monocotyledons and gymnosperms of Puerto Rico and the Virgin Islands. Smithsonian Contributions to Botany, 52, 1-415.

Acevedo-Rodríguez, P. \& Strong, M.T. (eds) (2012) Catalogue of seed plants of the West Indies. Smithsonian Contributions to Botany, 98, 1-1192.

Bailey, L.H. (1939) Coccothrinax in the southern Greater Antilles. Gentes Herbarum, 4, 247-259.

Berazaín Iturralde, R., Areces Berazaín, F., Lazcano Lara, J. C. \& GonzÁlez-Torres, L.R. (2005) Lista roja de la flora vascular cubana. Documentos del Jardín Botánico Atlántico de Gijón, 4, 1-86.

Brown, N., Geoghegan, T. \& Renard, Y. (2007) A Situation Analysis for the Wider Caribbean. IUCN, Gland, Switzerland. Http://portals.iucn.org/library/sites/library/files/documents/ 2007-035.pdf [accessed 25 March 2017].

Burret, M. (1929) Palmae cubenses et domingenses a Cl. E.L. Ekman 1914-1928 lectae. Kongliga Svenska Vetenskaps Akademiens Handlingar, 6, 1-28.

Burton, F.R. (2008) Threatened Plants of the Cayman Islands. The Red List. Royal Botanic Gardens, Kew, UK.

Carey, E., Gape, L., Manco, B.N., Hepburn, D., Smith, R.L., Knowles, L. et al. (2014) Plant conservation challenges in the Bahama archipelago. Botanical Review, 80, 265-282.

Duno de Stefano, R. \& Moya, C.E. (2014) A new record of Coccothrinax readii for Belize. Palms, 58, 72-76.

Enríquez Rodríguez, A., Robledo Ortega, L. \& Cruz Nardo, R. (2006) Notas sobre la distribución y conservación de Coccothrinax borhidiana (Arecaceae) en Cuba. Revista del Jardín Botánico Nacional, 27, 145-146.

Esposito, L. (2002) Integrative conservation. SAIS Review, 22, 53-75.

Freid, E., Francisco-Ortega, J. \& Jestrow, B. (2014) Endemic seed plants in the Bahamian Archipelago. Botanical Review, 8o, 204-230.

Galeano-Garces, G. (1986) Primer registro de dos géneros de palmas para la flora colombiana. Mutisia, 66, 1-4.

Gayle, D.J. \& Goodrich, J.N. (eds) (1993) Tourism Marketing and Management in the Caribbean. Routledge, New York, USA. 
González-Oliva, L., González-Torres, L.R., Palmarola, A. \& BArrios, D. (eds) (2014) Categorización de taxones de la flora de Cuba-2014. Bissea, 8 (Número Especial 1), 3-321.

González-Oliva, L., González-Torres, L.R., Palmarola, A., Barrios, D. \& Testé, E. (eds) (2015) Categorización de taxones de la flora de Cuba-2015. Bissea, 9 (Número Especial 4), 3-707.

González-Torres, L.R., Palmarola, A., González Oliva, L., Bécquer, E.R., Testé, E. \& BArrios, D. (eds) (2016) Lista roja de la flora de Cuba. Bissea, 10 (Número Especial 1), 1-352.

Greuter, W. \& Rankin, R. (2016) The Spermatophyta of Cuba. A Preliminary Checklist. Botanischer Garten \& Botanisches Museum, Berlin, Germany. Http://portal.cybertaxonomy.org/flora-cuba/ node/1 [accessed 25 March 2017].

Grisebach, A. (1866) Catalogus Plantarum Cubensium. Gulielmum Engelmann, Leipzig, Germany.

Henderson, A., Aubry, M., Timyan, J. \& Balick, M. (1990) Conservation status of Haitian palms. Principes, 34, 134-142.

Henderson, A., Galenao, G. \& Bernal, R. (1995) Field Guide to the Palms of the Americas. Princeton University Press, Princeton, USA.

Hershberg, E. \& LeoGrande, W.M. (eds) (2016) A New Chapter in US-Cuba Relations. Social, Political, and Economic Implications. Palgrave Macmillan, New York, USA.

Hingtgen, N., Kline, C., Fernandes, L. \& McGehee, N.G. (2015) Cuba in transition: tourism industry perceptions of entrepreneurial change. Tourism Management, 50, 184-193.

Hoyos Fernández, J. \& Braun, A. (2001) Palmas en Venezuela. Sociedad de Ciencias Naturales La Salle, Caracas, Venezuela.

IUCN (2001) IUCN Red List Categories and Criteria. Version 3.1. IUCN, Gland, Switzerland.

IUCN (2014) Guidelines for Using the IUCN Red List Categories and Criteria. Version 11. Http://www.iucnredlist.org/documents/ RedListGuidelines.pdf [accessed 25 March 2017].

Jestrow, B., Peguero, B., Jiménez, F., Cinea, W., Hass, M., Reeve, A. et al. (2016a) Genetic diversity and differentiation of the Critically Endangered Hispaniolan palm Coccothrinax jimenezii M.M. Mejía \& R.G. García based on novel SSR markers. Biochemical Systematics and Ecology, 66, 216-223.

Jestrow, B., Peguero, B., Joseph, P.A., Cinea, W. \& FranCISCO-ORTEGA, J. (2016b) Exploring the northern lowlands of Haiti. The Tropical Garden, 71(4), 21-25.

JudD, W.S. (1987) Floristic study of Morne La Visite and Pic Macaya national parks, Haiti. Bulletin of the Florida State Museum. Biological Sciences, 32, 1-136.

Leiva Sánchez, A.T. (1999) Las Palmas en Cuba. Editorial Científico-Técnica, Havana, Cuba.

Leiva Sánchez, A.T., Verdecia, R., Franco Flores, F., Ojeda, L. \& URQUiola, A. (2008) Estrategias integradas de conservación (I): protocolos para diez taxones de plantas vasculares amenazadas. Revista del Jardín Botánico Nacional, 29, 57-75.

LEÓN, B. (1939) Contribución al estudio de las palmas de Cuba. III. Memorias de la Sociedad Cubana de Historia Natural "Felipe Poey", 13, 107-156.

Liogier, A.H. (1978) Árboles Dominicanos. Academia de Ciencias de la República Dominicana, Santo Domingo, Dominican Republic.

Martínez Betancourt, J.I. (2016) Conservación de la "palma petate" en el occidente de Cuba. Bissea, 10 (Número Especial 1), 56.

Martínez Betancourt, J.I. \& Miranda, J. (2009-2010) Etnobotánica y educación para la conservación de Coccothrinax crinita subsp. crinita, palma petate (Arecaceae). Revista del Jardín Botánico Nacional, 30/31, 91-95.

Maunder, M., Abdo, M., Berazaín, R., Clubbe, C., Jiménez, F., Leiva, A. et al. (2011) The island plants of the Caribbean: a review of the biogeography, diversity and conservation of a storm battered hot-spot. In The Biology of Island Floras (eds D. Bramwell \&
J. Caujapé-Castells), pp. 154-178. Cambridge University Press, Cambridge, UK.

Maunder, M., Leiva, A., Santiago-Valentín, E., Stevenson, D. W., Acevedo-Rodríguez, P., Meerow, A.W. et al. (2008) Plant conservation in the Caribbean Island biodiversity hotspot. Botanical Review, 74, 197-207.

Maunder, M., Lyte, B., Dransfield, J. \& Baker, W. (2001) The conservation value of botanic garden palm collections. Biological Conservation, 98, 259-271.

McGowan, P.J.D., Traylor-Holzer, K. \& Leus, K. (2017) IUCN guidelines for determining when and how ex situ management should be used in species conservation. Conservation Letters, 10, 361-366.

Mejía, M. \& García, R. (1997) Una nueva especie de Coccothrinax (Arecaceae) para la Isla Española. Moscosoa, 9, 1-7.

Mejía, M. \& García, R. (2013) Una nueva especie de Coccothrinax (Arecaceae) para la Isla Española. Moscosoa, 18, 9-13.

Méndez Santos, I.E., Gueorguievich Elemevsky, A., Risco Villalobos, R., Martínez Jiménez, V. \& Trujillo Sánchez, R. (1989) Contribución al conocimiento de la flora y vegetación de la Sierra de Cubitas (Camagüey). Revista del Jardín Botánico Nacional, $10,147-173$.

Ministerio de Medio Ambiente y Recursos Naturales (2012) Estrategia Nacional de Especies Exóticas Invasoras Realizado en el Marco del Proyecto "Mitigando las Amenazas de las Especies Exóticas Invasoras en el Caribe Insular". Ministerio de Medio Ambiente y Recursos Naturales, Santo Domingo, Dominican Republic. Http:// ambiente.gob.do/wp-content/uploads/2016/10/Estretegia-Nacional. pdf [accessed 25 March 2017].

Moya, C.E. \& Leiva Sanchez, A.T. (200o) Checklist of the palms of Cuba, with notes on their ecology, distribution and conservation. Palms, 44, 69-84.

Moya, C.E., Morales Pérez, R., Méndez Santos, I.E. \& Martínez-Pentón, L.R. (2017a) Buscando la Coccothrinax camagueyana. Unpublished Abstract of Presentation. VII Jornada Nacional de Botánica-2017. Sociedad Cubana de Botánica and Jardín Botánico de Sancti Spiritus, Sancti Spiritus, Cuba.

Moya, C.E., Verdecia, R. \& Martínez-Pentón, L.R. (2017b) The Coccothrinax "azul" from Sancti Spiritus, Cuba. Palms, 61, 83-90.

Muñiz, O. \& Borhidi, A. (1981) Palmas nuevas del género Coccothrinax Sarg. en Cuba. Acta Botanica Academiae Scientiarum Hungaricae, 27, 439-454.

Muñiz, O. \& Borhidi, A. (1982) Catálogo de las palmas nuevas de Cuba. Acta Botanica Academiae Scientiarum Hungaricae, 28, 309-345.

Nauman, C.E. \& Sanders, R.W. (1991a) Preliminary classificatory studies in Coccothrinax (Palmae: Coryphoideae). Selbyana, 12, 91-101.

Nauman, C.E. \& Sanders, R.W. (1991b) An annotated key to the cultivated species of Coccothrinax. Principes, 35, 27-45.

Nelson, C. \& Proctor, G.R. (1994) Vascular plants of the Caribbean Swan Islands of Honduras. Brenesia, 41-42, 73-80.

OldField, S.F. (2009) Botanic gardens and the conservation of tree species. Trends in Plant Science, 14, 581-583.

Oviedo Prieto, R. \& González-Oliva, L. (2015) Lista nacional de plantas invasoras y potencialmente invasoras en la República de Cuba-2015. Bissea, 9 (Número Especial 1), 5-93.

Pasachnik, S.A., Carreras De León, R. \& León, Y.M. (2016) Protected only on paper? Three case studies from protected areas in the Dominican Republic. Caribbean Naturalist, 30, 1-19.

Peguero, B. \& Jiménez, F. (2011) Inventario y estado de conservación de las plantas vasculares exclusivas de la República Dominicana. Moscosoa, 17, 29-57.

Peguero, B., Jiménez, F., Joseph, P.A., Cinea, W., Griffith, M.P., Francisco-Ortega, J. \& Jestrow, B. (2015a) Coccothrinax 
jimenezii-a Critically Endangered palm from Hispaniola. Palms, 59, 145-153.

Peguero, B., Veloz, A., García, R., Clase, T., De Los Santos, C., Jones, D. \& Jiménez, F. (2011) Estado de conservación y utilidad del guano barrigón, Coccothrinax spissa Bailey (Arecaceae), especie endémica de la República Dominicana. In Manual de Herramientas Etnobotánicas Relativas a la Conservación y el Uso Sostenible de los Recursos Vegetales (eds S. Lagos-Witte, O.L. Sanabria Diago, P. Chacón \& R. García), pp. 123-134. Red Latinoamericana de Botánica, Santiago de Chile, Chile.

Peguero, B., Veloz, A., García, R., Clase, T., De Los Santos, C., Jones, D. \& Jiménez, F. (2015b) Estado de conservación de las palmas de la Isla Española. Moscosoa, 19, 139-147.

Petriello, M.A. \& Wallen, K.E. (2015) Integrative reflections on the new conservation science debate. Biodiversity and Conservation, 24, 1549-1551.

Powell, R. \& Inchaustegui, S.J. (2009) Conservation of the herpetofauna of the Dominican Republic. Applied Herpetology, 6, 103-122.

Pritchard, D.J., Fa, J.E., Oldfield, S. \& Harrop, S.R. (2012) Bring the captive closer to the wild: redefining the role of ex situ conservation. Oryx, 46, 18-23.

Proctor, R.G. (2012) Flora of the Cayman Islands. Edition 2. Royal Botanic Gardens, Kew, UK.

Rankin Rodríguez, R. \& Areces Berazaín, F. (2003) Contribución a la actualización taxonómica y localización geográfica de especies amenazadas y endémicas en Cuba I. Revista del Jardín Botánico Nacional, 24, 81-128.

Rodríguez, R. (2014) Genetic diversity and conservation of Pseudophoenix (Arecaceae) in Hispaniola. MSc thesis. Florida International University, Miami, USA.

Romero Luna, E.J. \& Poteau, D. (2011) Water Level Fluctuations of Lake Enriquillo and Lake Saumatre in Response to Environmental Changes. Unpublished Masters of Engineering Project. Cornell University, Ithaca, USA. Https://ecommons.cornell.edu/handle/ 1813/23555 [accessed 25 March 2017].

Roncal, J., Zona, S. \& Lewis, C.E. (2008) Molecular phylogenetic studies of Caribbean palms (Arecaceae) and their relationships to biogeography and conservation. Botanical Review, 74, 78-102.

Suárez Oropesa, D. (2015) Coccothrinax $\times$ angelae (Arecaceae), nuevo híbrido natural del género para Cuba. Revista del Jardín Botánico Nacional, 36, 9-14.

Suárez Oropesa, D., Sosa Rodríguez, F.M., Vega Marrero, G., Gómez Brito, R. \& Panfet Valdés, C.M. (2013) Conservación de las palmas (Arecaceae) en el Macizo Guamuhaya, provincia Cienfuegos. Revista Centro Agrícola, 40, 63-67.
Urquiola Cruz, A.J., González-Oliva, L., Novo Carbó, R. \& Acosta Ramos, Z. (2010) Libro Rojo de la Flora Vascular de la Provincia de Pinar del Río. Publicaciones de la Universidad de Alicante, San Vicente del Raspeig, Spain.

Veloz, A., Peguero, B. \& Clase, T. (2011) Aspectos ecológicos, distribución, germinación, usos, amenazas y estado de conservación de las especies Copernicia berteroana Becc., Coccothrinax spissa Bailey, Reinhardtia paiewonskiana R. W. Read, T. A. Zanoni \& M. Mejía, $y$ Thrinax radiata Lodd. (Arecaceae) en la República Dominicana. Unpublished report. Jardín Botánico Nacional de Santo Domingo Dr. Rafael M. Moscoso, Consejo Nacional de Investigaciones Agropecuarias y Forestales y Consorcio Ambiental Dominicano, Santo Domingo, Dominican Republic.

Verdecia, R. (2015) Palms of Cuba. Todas las Palmas de Cuba. Florida Keys TREE Institute, Key West, USA.

Verdecia, R., Gómez, J.L., Leyva Bermúdez, O. \& Hernández Montero, Y. (2014) Coccothrinax rigida 150 años después de Charles Wright. Bissea, 8(3), 2.

Wacaster, S., Baker, M.S., Soto-Viruet, Y. \& Textoris, S. (2015) Recent trends in Cuba's mining and petroleum industries (version 1.1). U.S. Geological Survey Fact Sheet 2015-3032, https://dx.doi.org/ $10.3133 /$ fs20153032.

ZonA, S. (1997) The genera of Palmae (Arecaceae) in the southeastern United States. Harvard Papers in Botany, 2, 71-107.

Zona, S., Verdecia, R., Leiva Sánchez, A., Lewis, C.E. \&

MAUnder, M. (2007) The conservation status of West Indian palms (Arecaceae). Oryx, 41, 300-305.

\section{Biographical sketches}

BRETT JESTROW is a herbarium curator and is specialized in tropical plant systematics. BRígido PEGUERo leads plant exploration activities in the Dominican Republic. Francisco Jiménez is the head of the botany programme at Jardín Botánico Nacional in the Dominican Republic. RAÚL VERDECIA leads projects focused on the biodiversity of Cuban palms. LISBET GonZALEZ-OLIVA is a conservation biology researcher interested in Cuban threatened species. Celio Moya is a palm biologist who has worked for the Jardín Botánico de Sancti Spíritus, Cuba and for Gemini Botanic Garden, Florida. William Cinea has an interest in plant conservation and botanic garden management. M. PATRICK GRIFFITH is specialized in ex situ conservation in botanic gardens. Alan MEERow is a senior research geneticist and systematist. MIKE MAUNDER is a conservationist with a focus on tropical plant species. JAVIER FRANCISCO-ORTEGA has an interest in Caribbean plant biodiversity. 